\title{
Stenotrophomonas acidaminiphila sp. nov., a strictly aerobic bacterium isolated from an upflow anaerobic sludge blanket (UASB) reactor
}

\footnotetext{
${ }^{1}$ Département de Biochimie-Microbiologie, Faculté des Sciences et Techniques, Université de Ouagadougou, 03 BP 7021 , Ouagadougou 03, Burkina Faso

2 Departamento de Biotecnología, Universidad Autónoma MetropolitanaIztapalapa, Avenida Michoacán y la Purisima s/n, Col. Vicentina, 09340 México DF, Mexico

${ }^{3}$ Institut de Recherche pour le Développement (IRD), Cicerón 609, Col. Los Morales, 11530 México DF, Mexico

${ }^{4}$ Laboratoire de Microbiologie IRD, IFRBAIM, Universités de Provence et de la Méditerranée, ESIL case 925,163 avenue de Luminy, 13288 Marseille cedex 9, France
}

\author{
Essokazi A. Assih, ${ }^{1}$ Aboubakar S. Ouattara, ${ }^{1}$ Sébastien Thierry, ${ }^{2,3}$ \\ Jean-Luc Cayol, ${ }^{4}$ Marc Labat $^{4}$ and Hervé Macarie ${ }^{2,3}$
}

Author for correspondence: Aboubakar S. Ouattara. Tel: +2263373 73. Fax: +226337373. e-mail: ouattabs@univ-ouaga.bf

\begin{abstract}
Two of several strictly aerobic, mesophilic bacteria isolated from a lab-scale upflow anaerobic sludge blanket (UASB) reactor treating a petrochemical wastewater, strains AMX 17 and AMX 19', were subjected to detailed taxonomic study. Cells were Gram-negative, motile, non-sporulating, straight to curved rods with a polar flagellum. The isolates exhibited phenotypic traits of members of the genus Stenotrophomonas, including cellular fatty acid composition and the limited range of substrates that could be used. Sugars and many amino acids were utilized. Antibiotic susceptibility and physiological characteristics were determined. The DNA base composition was $66.9 \mathrm{~mol} \%$ $G+C$. Phylogenetic analysis revealed that the nearest relatives were Stenotrophomonas maltophilia LMG 11114, Stenotrophomonas nitritireducens DSM $12575^{\top}$ and Pseudomonas pictorum ATCC $23328^{\top}$ (similarity of 98.1-98.8\%). Xanthomonas species, S. maltophilia LMG $958^{\mathrm{T}}$ and Stenotrophomonas africana CIP 104854' showed high 16 S rRNA sequence similarities (96.4-97.3\%). The high similarity found in cellular fatty acid profiles and identical partial 16S rRNA sequences (500 bp) for strains AMX 17 and AMX 19' indicate that they belong to the same species. DNA-DNA hybridizations revealed respectively $26 \cdot 7,31$, 65.8 and $43.6 \%$ homology between isolate AMX $19^{\top}$ and S. africana CIP 104854', S. maltophilia CIP $60.77^{\top}$, S. nitritireducens DSM $12575^{\top}$ and $P$. pictorum ATCC

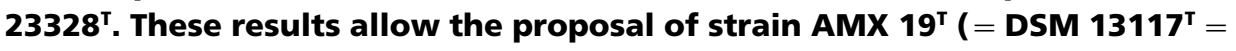
ATCC $700916^{\top}=$ CIP $^{106456}{ }^{\top}$ ) as representative of a novel species of the genus Stenotrophomonas, with the name Stenotrophomonas acidaminiphila sp. nov.
\end{abstract}

Keywords: polyphasic taxonomy, cellular fatty acids, amino acids, anaerobic reactor, Xanthomonas

\section{INTRODUCTION}

Anaerobic digesters are complex, man-made biotopes, used for treatment of wastewater, sludge and organic solids, where both strictly anaerobic and aerobic bacteria can co-exist (Guyot et al., 1994; Noeth et al., 1988; Toerien \& Hattingh, 1969). Surveys of bacterial population types have revealed the presence, in these Abbreviations: CFA, cellular fatty acid; UASB, upflow anaerobic sludge
blanket.

The GenBank/EMBL/DDBJ accession number for the $16 \mathrm{~S}$ rRNA gene sequence of strain $A M X 19^{\top}$ is $A F 273080$. ecosystems, of aerobic, non-sporulating, Gram-negative, flagellated, chemo-organotrophic proteobacteria that possess a strictly respiratory energy-yielding metabolism (Britz et al., 1994; Hakulinen et al., 1985; $\mathrm{Ng}$ et al., 1994; Toerien \& Hattingh, 1969). A wide diversity of genera, including Stenotrophomonas, are members of this heterogeneous group with versatile metabolisms. Initially containing a single species, Stenotrophomonas maltophilia, the number of species of the genus Stenotrophomonas has increased to three with the recent characterization and description of Stenotrophomonas africana (Drancourt et al., 1997) and Stenotrophomonas nitritireducens (Finkmann et 
al., 2000). The original member of the genus, $S$. maltophilia, originally isolated from human pleural fluid and named 'Bacterium bookerii', was validly described as Pseudomonas maltophilia (Hugh \& Ryschenkow, 1961) before being renamed Xanthomonas maltophilia on the basis of quinone type, cellular fatty acid (CFA) composition, enzyme characterization and DNA-rRNA hybridization results (Swings et al., 1983). However, the affiliation of $P$. maltophilia to the genus Xanthomonas was subject to criticism (Van Zyl $\&$ Steyn, 1992), and a further reclassification of $X$. maltophilia to $S$. maltophilia was proposed (Palleroni \& Bradbury, 1993).

This species has been the object of several taxonomic studies (Hauben et al., 1999; Moore et al., 1997; Palleroni \& Bradbury, 1993; Stanier et al., 1966; Van den Mooter \& Swings, 1990; Vauterin et al., 1995; Wang et al., 1998). Stenotrophomonas species are common inhabitants of a wide variety of natural and artificial environments such as water, sediments, plant rhizospheres, corroded metal surfaces, waste-gas biofilters, aquaculture tanks, oilfields, sewage and anaerobic reactors (Aznar et al., 1992; Boonchan et al., 1998; Borowicz et al., 1995; Britz et al., 1994; Finkmann et al., 2000; Hauben et al., 1999; Juhnke et al., 1987; Lambert et al., 1990; Leifert \& Waites, 1992; Wallace et al., 1994; Wilkinson et al., 1994) and can be opportunistic human pathogens (Drancourt et al., 1997; Denton \& Kerr, 1998).

In an attempt to determine the role of strictly aerobic bacteria in anaerobic digesters, enumeration and identification of these micro-organisms was performed from a laboratory-scale upflow anaerobic sludge blanket (UASB) reactor fed with the wastewater of a petrochemical company producing purified terephthalic acid (1,4-benzenedicarboxylic acid). Several strains were isolated and subjected to identification by classical biochemical character determination, CFA composition analysis and/or partial 16S rRNA sequence analysis. Most of the isolates could be identified accurately by the set of taxonomic tools but some were not readily identifiable. Among this last group of micro-organisms, several strains, AMX strains 15, 17, $18,19^{\mathrm{T}}$ and 312 , could be arranged in the same cluster based on their CFA profiles. Strains AMX 17 and AMX $19^{\mathrm{T}}$ were then subjected to more detailed taxonomic study. We report the characterization of strains AMX 17 and AMX $19^{\mathrm{T}}$ as a novel species of the genus Stenotrophomonas, Stenotrophomonas acidaminiphila sp. nov., with strain AMX $19^{\mathrm{T}}$ (= DSM $13117^{\mathrm{T}}=$ ATCC $700916^{\mathrm{T}}=$ CIP $106456^{\mathrm{T}}$ ) as the type strain.

\section{METHODS}

Source of organisms. Strains AMX 17 and AMX 19 ${ }^{\mathrm{T}}$ were isolated from the anaerobic sludge of a laboratory-scale UASB reactor using R2A medium (Oxoid). The reactor, fed with settled, genuine, terephthalic-acid-plant wastewater supplemented with nitrogen, phosphorous, sulfur and trace metals, was operated at a constant organic loading rate of
$2 \cdot 25 \mathrm{~g} \mathrm{COD}_{\text {reactor }}^{-1} \mathrm{day}^{-1}\left[0 \cdot 1 \mathrm{~g} \mathrm{COD}\left(\mathrm{g} \mathrm{VSS}^{-1} \mathrm{day}^{-1}\right](\mathrm{COD}\right.$, chemical oxygen demand; VSS, volatile suspended solids) and a hydraulic retention time of 2 days. The temperature in situ averaged $33^{\circ} \mathrm{C}$ and the $\mathrm{pH}$ was near $7 \cdot 4$. The main organic compounds present in the wastewater were acetic, benzoic, $p$-toluic (4-methylbenzoic), trimellitic (1,2,4-benzenetricarboxylic) and terephthalic acids, as well as 4carboxybenzaldehyde (4-formylbenzoic acid) and ethylene glycol (Fajardo et al., 1997). By the time of isolation, the reactor was fed with non-sterilized wastewater and could be considered in stationary phase, since it presented constant biogas production $\left(1.081 \mathrm{day}^{-1}\right.$ at $\left.1 \mathrm{~atm}, 0{ }^{\circ} \mathrm{C}\right)$ and COD removal $(80 \pm 6 \%)$. Purifications were performed by streaking colonies onto Petri dishes containing medium R2A or plate count agar (Difco). The purity of isolates was checked in a complex medium containing $0.5 \%$ yeast extract, $0.5 \%$ peptone, $0.5 \%$ Bio-trypticase, $0.5 \%$ Casamino acids and $0.25 \%$ glucose. The culture was examined microscopically after $1-3$ weeks of incubation. S. maltophilia CIP $60.77^{\mathrm{T}}$ and $S$. africana CIP $104854^{\mathrm{T}}$ were obtained from the Collection de l'Institut Pasteur (CIP), S. nitritireducens DSM 12575 was from the DSMZ and $P$. pictorum ATCC $23328^{\mathrm{T}}$ was from the ATCC.

Media and culture conditions. With the exception of the isolation and purification procedures, all procedures were performed in liquid medium using standard techniques for cultivation of strict aerobes. For nutritional tests, strains were grown on a basal medium containing $\left(1^{-1}\right): 0.25 \mathrm{~g}$ $\mathrm{KH}_{2} \mathrm{PO}_{4}, 0.30 \mathrm{~g} \mathrm{NH} \mathrm{Nl}_{4}, 1 \mathrm{~g} \mathrm{NaCl}, 0.50 \mathrm{~g} \mathrm{KCl}, 0.40 \mathrm{~g}$ $\mathrm{MgCl}_{2} \cdot 6 \mathrm{H}_{2} \mathrm{O}, 0 \cdot 16 \mathrm{~g} \mathrm{CaCl} 2.2 \mathrm{H}_{2} \mathrm{O}$ and $0 \cdot 10 \mathrm{~g}$ Casamino acids. Media were dispensed into tubes or flasks and sterilized at $120^{\circ} \mathrm{C}$ for $18 \mathrm{~min}$. Just before inoculation, substrates (sugars, organic acids or amino acids) were supplied from filter-sterilized stock solutions in order to reach a final concentration of $10 \mathrm{mM}$, except for the aromatic amino acids, which were added at $1 \mathrm{~g} \mathrm{l}^{-1}$, and the racemic mixtures, which were prepared at $20 \mathrm{mM}$.

Determination of optimal growth conditions $(\mathrm{pH}$, temperature) was conducted in a rich culture medium (basal medium supplemented with $5 \mathrm{~g}$ Casamino acids and $2 \mathrm{~g}$ yeast extract $1^{-1}$ ). The $\mathrm{pH}$ was fixed at 7 when testing temperature and the temperature at $35^{\circ} \mathrm{C}$ when testing $\mathrm{pH}$. Growth was monitored by measuring the optical density at $580 \mathrm{~nm}$. The ranges tested for growth were $\mathrm{pH} 5 \cdot 0-9 \cdot 5$ and 4-50 ${ }^{\circ} \mathrm{C}$.

General phenotypic characteristics. Phenotypic characterization of isolate AMX $19^{\mathrm{T}}$ was based on Gram staining, motility, respiratory, catalase and oxidase tests (Diagnostics Pasteur). Further biochemical analysis was performed by inoculating API $20 \mathrm{NE}$ and API $50 \mathrm{CH}$ strips (bioMérieux) according to the manufacturer's instructions. The cell morphology was determined from direct observations of fresh cultures using a Nikon phase-contrast microscope or exponentially grown cells negatively stained with $1 \%$ sodium phosphotungstic acid $(\mathrm{pH} 7 \cdot 2)$ with a Hitachi model H600 transmission electron microscope operated at an accelerating voltage of $75 \mathrm{kV}$. The presence, number and position of flagella were determined both by flagellar staining and by electron microscopy.

Antibiogram. Susceptibility of strain AMX $19^{\mathrm{T}}$ to 15 antibiotics was tested by Pasteur Cerba (Paris, France) using the Kirby-Bauer disk-diffusion method (Bauer et al., 1966) on Mueller-Hinton solid medium $\left(1^{-1}: 3 \mathrm{~g}\right.$ beef infusion, $17.5 \mathrm{~g}$ Casamino acids, $1.5 \mathrm{~g}$ starch, $17 \mathrm{~g}$ agar). Inhibition diameters were recorded after $24 \mathrm{~h}$ of incubation at $37^{\circ} \mathrm{C}$ 
under aerobic conditions. The classification of each strain as sensitive, not sensitive or intermediately sensitive to the antibiotic was done according to the disk manufacturer's instructions (Sanofi Diagnostics Pasteur), based on the directives of the French antibiogram committee (Comité de l'antibiogramme de la Société Française de Microbiologie, 1997). The antibiotics tested correspond to those presently recommended for Pseudomonas aeruginosa and other Gramnegative aerobes. They cover the different mechanisms of antibiotic action (inhibition of synthesis of peptidoglycan, proteins, nucleic acids and folate and disruption of membranes).

CFA analysis. The CFA compositions of strains AMX 17 and AMX $19^{\mathrm{T}}$ and also those of collection strains were determined by Microbial ID, Inc., using the Sherlock Microbial Identification System software (MIDI Inc.). Prior to analysis, reference strains and isolates were cultivated in trypticase soy broth agar at $28^{\circ} \mathrm{C}$ for $24 \mathrm{~h}$. CFA were extracted and analysed by following the instructions and standard procedures of Microbial ID, Inc. (Miller, 1982; Sasser, 1990).

Nitrate and nitrite reduction. A preliminary examination of the ability of the strains to reduce nitrate and nitrite was performed by the traditional colorimetric procedure (Smibert \& Krieg, 1994). This test consists of the addition, after incubation, to the culture medium supplemented with nitrate or nitrite, of sulfanilic acid and $N, N$-dimethyl-1-naphthylamine, which react with nitrite to produce a pink/red coloration. The presence of colour in the medium supplemented with nitrate is indicative of its reduction to nitrite, while an absence of coloration in the medium supplemented with nitrite is indicative of its reduction. In case no colour appeared in the medium supplemented with nitrate, zinc powder, which converts nitrate to nitrite, was also added in order to confirm that nitrate was reduced further than nitrite and did not remain in the medium. The ability of the strain to reduce nitrate was double-checked with the API $20 \mathrm{NE}$ strips inoculated for biochemical analysis. Nitrate and nitrite reduction were later confirmed by inoculating, in each case, three tubes containing $10 \mathrm{ml}$ of the following sterile medium $\left(1^{-1}\right): 5 \cdot 1 \mathrm{~g} \mathrm{Na}_{2} \mathrm{HPO}_{4}, 1 \cdot 1 \mathrm{~g} \mathrm{NaH}_{2} \mathrm{PO}_{4}, 5 \cdot 0 \mathrm{~g} \mathrm{~K}_{2} \mathrm{HPO}_{4}, 0 \cdot 229 \mathrm{~g}$ $\mathrm{NH}_{4} \mathrm{Cl} ; 0.033 \mathrm{~g} \mathrm{FeSO}_{4} .7 \mathrm{H}_{2} \mathrm{O}$ and $3 \mathrm{ml}$ of a trace metal solution (El-Mamouni et al., 1995). $\mathrm{CH}_{3} \mathrm{COONa} .3 \mathrm{H}_{2} \mathrm{O}$ $\left(6.8 \mathrm{~g} \mathrm{l}^{-1}, 50 \mathrm{mM}\right)$ was used as the carbon source, while nitrate and nitrite were added as $\mathrm{NaNO}_{3}$ and $\mathrm{NaNO}_{2}$ at concentrations of 100 and $150 \mathrm{mM}$, sufficient to allow the oxidation of all the acetate. At these concentrations, neither nitrate nor nitrite appeared to produce significant inhibition of growth of strain AMX $19^{\mathrm{T}}$. The medium was made anoxic by boiling under a flow of carbon dioxide, which also corresponded to the final atmosphere of the tubes. With this mode of preparation, the $\mathrm{pH}$ of the medium after inoculation $(10 \% \mathrm{v} / \mathrm{v})$ was around 7 . The reduction of nitrate and nitrite was monitored by following their disappearance as well as the formation of $\mathrm{N}_{2} \mathrm{O}$ in the gaseous phase and ammonium in the aqueous phase. Molecular nitrogen was not followed, since it was impossible to obtain an $\mathrm{N}_{2}$-free atmosphere by bubbling $\mathrm{CO}_{2}$ or other gases (i.e. helium).

DNA base determination. The $\mathrm{G}+\mathrm{C}$ content of the DNA of strain AMX $19^{\mathrm{T}}$ was determined by HPLC at the 'DSMZ', with non-methylated $\lambda$ phage DNA as the reference. Procedures for isolation and determination were from Cashion et al. (1977) and Mesbah et al. (1989).

16S rRNA sequencing and phylogeny. Extraction of DNA from strains AMX 17 and AMX 19 19 , 16S rRNA gene amplification, purification and sequencing were performed by MIDI Labs. The $16 \mathrm{~S}$ rRNA gene was amplified by PCR from genomic DNA isolated from bacterial colonies. Primers 005F and 1540R (F, forward; R, reverse; Lane, 1991) used for the amplification of the full-length sequence (strain AMX $19^{\mathrm{T}}$ ) correspond to Escherichia coli positions 5 and 1540 and primers $005 \mathrm{~F}$ and $531 \mathrm{R}$, used for the partial, $500 \mathrm{bp}$ sequence (strain AMX 17), correspond to positions 5 and 531. Amplification products were purified using Microcon 100 molecular mass cut-off membranes (Amicon) and checked for quality and quantity by running a portion of the products on an agarose gel. Cycle sequencing of the $16 \mathrm{~S}$ rRNA amplification products was carried out using AmpliTaq FS DNA polymerase and dRhodamine dye terminators. Excess dye-labelled terminators were removed from the sequencing reactions using Sephadex G-50 spin columns. The products were collected by centrifugation, dried under vacuum and frozen at $-20{ }^{\circ} \mathrm{C}$ until ready to load. Samples were resuspended in a solution of formamide/blue dextran/ EDTA and denatured prior to loading. The samples were electrophoresed on an ABI Prism 377 DNA sequencer. Data were analysed using the PE/Applied Biosystems DNA editing and assembly software. The primers used for sequencing were $005 \mathrm{~F}, 338 \mathrm{~F}, 357 \mathrm{R}, 515 \mathrm{~F}, 531 \mathrm{R}, 776 \mathrm{~F}, 810 \mathrm{R}$, $1087 \mathrm{~F}, 1104 \mathrm{R}, 1174 \mathrm{~F}, 1193 \mathrm{R}$ and 1540R. The 16S rRNA gene sequence obtained was aligned manually with reference sequences extracted from the RDP (Maidak et al., 1996) and GenBank databases. Positions of sequence and alignment uncertainty were omitted from the analysis. Pairwise evolutionary distances based on 1432 unambiguous nucleotides were computed by using the method of Jukes \& Cantor (1969) and dendrograms were constructed from these distances by the neighbour-joining method. The reliability of the trees was evaluated by the bootstrap procedure. All programs used form part of the PHYLIP package (Felsenstein, 1993).

DNA-DNA hybridization. Spectroscopic DNA-DNA hybridization was performed at the DSMZ. DNA was isolated according to Cashion et al. (1977). DNA-DNA hybridizations were carried out as described by De Ley et al. (1970), with the modifications made by Escara \& Hutton (1980) and Huß et al. (1983), using a Gilford System model 2600 spectrometer equipped with a Gilford model 2527-R thermoprogrammer and plotter. Renaturation rates were computed using the program TRANSFER.BAS (Jahnke \& Bahnweg, 1986; Jahnke, 1992). The hybridization percentages obtained with this technique presented a standard deviation of less than $2.5 \%$. Values close to $70 \%$ were re-checked in order to confirm the results.

Analytical techniques. Substrate concentrations were determined by HPLC (Spectra Series 100 model; Thermo Separation Products) connected to a differential refractometer (RID-6A Shimadzu). The mobile phase was $2.5 \mathrm{mM}$ $\mathrm{H}_{2} \mathrm{SO}_{4}$ at a flow rate of $0.6 \mathrm{ml} \mathrm{min}^{-1}$ and the column temperature was $35^{\circ} \mathrm{C}$. The volume of the injection loop was $20 \mu \mathrm{l}$. Peak analysis was performed using a CR-6A Shimadzu integrator. Amino acids were assayed using an Aminex HPX-87X column [300 × 7.8 (i.d.) mm] (Bio-Rad) and carbohydrates, organic acids, alcohols and volatile fatty acids with an ORH-801 column $[300 \times 6.5$ (i.d.) $\mathrm{mm}]$ (Interaction Chemicals, Inc.). The concentrations of nitrate and nitrite were measured with a capillary ion analyser (Waters 4000 ; Millipore) according to Gomez et al. (1996). $\mathrm{N}_{2} \mathrm{O}$ was detected with a Varian 3350 GC equipped with a thermal conductivity detector and a stainless steel column $[2000 \times 3 \cdot 2$ (i.d.) $\mathrm{mm}$ ] packed with Porapak Q. Separation was obtained 
with the following conditions: injector temperature, $100{ }^{\circ} \mathrm{C}$; column temperature, $35^{\circ} \mathrm{C}$; detector temperature, $110^{\circ} \mathrm{C}$; filament temperature, $135^{\circ} \mathrm{C}$; carrier gas, helium at $16 \mathrm{ml} \mathrm{min}{ }^{-1}$. Gas sampling was performed with a pressurelock syringe and a volume of $0.1 \mathrm{ml}$ was injected. The concentration of ammonium was determined by the colorimetric method of Nessler as described by Daniels et al. (1994).

\section{RESULTS}

\section{Morphology, growth, metabolic properties and antibiotic susceptibility}

After 2-10 days at $30^{\circ} \mathrm{C}$, strains AMX 17 and AMX $19^{\mathrm{T}}$ formed yellow, circular colonies on trypticase soy agar. Growth was not accompanied by odour. Cells of isolate AMX $19^{\mathrm{T}}$ were straight to curved rods, highly motile, that stained Gram-negative and possessed monotrichous polar flagellation. Spore formation was not observed. The cells occurred singly or in pairs and were $0.5 \times 1.5-2.5 \mu \mathrm{m}$ in size. Tests for catalase, oxidase, Tween 80 esterase, nitrite and nitrate reductases and aesculin hydrolysis were positive while tests for indole, DNase, lysine and ornithine decarboxylases, $o$ nitrophenyl $\beta$-D-galactopyranoside and $p$-nitrophenyl $\beta$-D-galactopyranoside, arginine dihydrolase as well as urease, Simmons' citrate, amylase and proteolysis were negative. Strain AMX $19^{\mathrm{T}}$ was strictly aerobic, as shown by the absence of growth after 1 month of incubation at $35^{\circ} \mathrm{C}$ in an anaerobic jar on R2A medium. However, growth was possible under anoxic conditions, coupled to nitrate and nitrite consumption, with acetate as the sole carbon source. Since ammonium accumulation was not observed in the medium and only traces of $\mathrm{N}_{2} \mathrm{O}$ were detected (data not shown) in the gas phase of old cultures (40 days incubation), we assumed that strain AMX $19^{\mathrm{T}}$ was able to perform the complete reduction of both compounds to $\mathrm{N}_{2}$. Growth was obtained when organic acids, sugars, amino acids, Casamino acids and peptone from casein were used as carbon sources (Table 1). Fastest growth and greatest biomass recovery were observed with Casamino acids and peptone from casein. Degradation of tyrosine and phenylalanine was accompanied by a pink coloration of the culture medium. Benzoate was initially used as a carbon source. This ability was, however, lost quickly upon subculturing on R2A agar or any rich medium. Susceptibility of the growth of isolate AMX $19^{\mathrm{T}}$ to antibiotics was observed with all the aminoglycosides, fluoroquinolones, polypeptides and sulfamides tested, which are characterized by modes of action not based on the inhibition of peptidoglycan synthesis. In this latter group of antibiotics, susceptibility to the cephems and penicillins studied was variable, while resistance was observed with the only carbapenem examined (Table 2).

Growth was observed above $20{ }^{\circ} \mathrm{C}$ (the lower limit was between $4{ }^{\circ} \mathrm{C}$, at which no growth occurred, and $20^{\circ} \mathrm{C}$, but was not determined with precision) and below
$42{ }^{\circ} \mathrm{C}$, with an optimum at $30-35^{\circ} \mathrm{C}$. The $\mathrm{pH}$ range of growth was $5 \cdot 0-9 \cdot 0$, with optimal growth at $\mathrm{pH} 6 \cdot 0-7 \cdot 0$.

\section{CFA analysis}

The three CFA (11:0 iso; $11: 0$ iso $3 \mathrm{OH}$ and 13:0 iso $3 \mathrm{OH}$ ) identified by Yang et al. (1993) as characteristic of the genera Stenotrophomonas and Xanthomonas were detected in the CFA patterns of AMX 17 and AMX $19^{\mathrm{T}}$ (Table 3). Comparison of the CFA profiles of these strains to those of all Stenotrophomonas species described so far and 11 Xanthomonas species present in the Microbial ID database by unweighted arithmetic average clustering showed that these micro-organisms clustered with $S$. nitritireducens DSM $12575^{\mathrm{T}}$ but separately from the other Stenotrophomonas species and from the Xanthomonas species (Fig. 1). In the same analysis, strains AMX 17 and AMX 19 ${ }^{\mathrm{T}}$ linked together at a Euclidian distance of 3, which indicates that the two organisms have very similar CFA patterns. Their CFA profiles showed several differences from those of $S$. maltophilia CIP $60.77^{\mathrm{T}}, S$. africana CIP $104854^{\mathrm{T}}$ and S. nitritireducens DSM $12575^{\mathrm{T}}$ (Table $3)$. The main differences from these species are: (i) the presence (even if only as traces) of 10:0 iso, 12:0 iso, $13: 0$ anteiso, $14: 1 \omega 5 c, 15: 1 \omega 6 c$ and $16: 1$ iso $\mathrm{H}$ fatty acids; (ii) larger amounts of $14: 0$ iso and particularly 16:0 iso; and (iii) smaller amounts of 15:0 anteiso. The 17:0 cyclo fatty acid reported as distinctive for $S$. nitritireducens by Finkmann et al. (2000) was also absent from both strains, while they possessed 10:0, $18: 1 \omega 9 c$ and $18: 1 \omega 7 c$, not detected in the latter species. The differences observed between our results and CFA patterns reported previously for S. maltophilia (Yang et al., 1993) and S. nitritireducens (Finkmann et al., 2000) are probably the result of different times (48 or $72 \mathrm{~h}$ instead of $24 \mathrm{~h}$ ) and/or temperatures $\left(25\right.$ against $\left.28^{\circ} \mathrm{C}\right)$ of incubation.

\section{Genotypic analysis}

The $\mathrm{G}+\mathrm{C}$ content of isolate AMX $19^{\mathrm{T}}$ was $66.9 \pm$ $0.5 \mathrm{~mol} \%$ (three determinations). A total of $15 \overline{42}$ positions of its 16S rRNA gene were sequenced. Phylogenetic analysis revealed that the closest relatives were S. maltophilia LMG 11114 , S. nitritireducens DSM $12575^{\mathrm{T}}$ and $P$. pictorum ATCC $23328^{\mathrm{T}}$, with similarity levels of $98.8,98.6$ and $98.0 \%$, respectively. S. africana CIP $104854^{\mathrm{T}}$, Xanthomonas arboricola LMG $747^{\mathrm{T}}$, Xanthomonas axonopodis LMG $538^{\mathrm{T}}$ and Xanthomonas campestris LMG 726 were the next nearest relatives, with similarity values of $96 \cdot 4-97 \cdot 3 \%$ (Fig. 2). The type strain of S. maltophilia, LMG $958^{\mathrm{T}}$, presented only $96.7 \%$ similarity. No differences were observed between the $500 \mathrm{bp}$ sequenced from strain AMX 17 and the corresponding sequence from strain AMX $19^{\mathrm{T}}$. DNA-DNA hybridization revealed $26 \cdot 7$, $31 \cdot 0,43.6$ and $65 \cdot 8 \%$ similarity, respectively, between isolate AMX $19^{\mathrm{T}}$ and $S$. africana CIP $104854^{\mathrm{T}}, S$. maltophilia CIP $60.77^{\mathrm{T}}$, P. pictorum ATCC $23328^{\mathrm{T}}$ and $S$. nitritireducens DSM $12575^{\mathrm{T}}$. The level of DNA hybridization between the type strains of $S$. africana 
Table 1. Substrate utilization by strain AMX $19^{\top}$

Utilization is scored as: + , utilized; $+^{*}$, utilized with slight increase in OD; $(+)$, slow and poor use without increase in $\mathrm{OD} ;(\mathrm{v})$, variable; - , not utilized.

\begin{tabular}{|c|c|}
\hline Compound & Utilization \\
\hline \multicolumn{2}{|c|}{ Amino acids and related compounds } \\
\hline DL-Alanine & + \\
\hline L-Arginine & + \\
\hline L-Asparagine & + \\
\hline DL-Aspartate & + \\
\hline L-Cysteine & + \\
\hline L-Glutamate & + \\
\hline L-Glutamine & + \\
\hline DL-Histidine & + \\
\hline L-Isoleucine & + \\
\hline DL-Leucine & + \\
\hline L-Phenylalanine & + \\
\hline L-Proline & + \\
\hline L-Serine & + \\
\hline DL-Threonine & + \\
\hline DL-Tyrosine & + \\
\hline DL-Valine & + \\
\hline Glycine & - \\
\hline L-Lysine & - \\
\hline L-Methionine & - \\
\hline D-Ornithine & - \\
\hline DL-Tryptophan & - \\
\hline Casamino acids & + \\
\hline Peptone from casein & + \\
\hline \multicolumn{2}{|c|}{ Sugars and related compounds } \\
\hline$N$-Acetylglucosamine & + \\
\hline Maltose & + \\
\hline D-Mannose & + \\
\hline D-Cellobiose & - \\
\hline Amygdalin & - \\
\hline D-Arabinose & - \\
\hline L-Arabinose & - \\
\hline Arbutin & - \\
\hline D-Fructose & + \\
\hline D-Fucose & - \\
\hline L-Fucose & - \\
\hline D-Galactose & - \\
\hline$\beta$-Gentiobiose & - \\
\hline D-Glucose & + \\
\hline Methyl $\beta$-D-glucoside & - \\
\hline Glycogen & - \\
\hline Inulin & - \\
\hline Lactose & - \\
\hline D-Lyxose & - \\
\hline Methyl $\alpha$-D-mannoside & - \\
\hline Melezitose & - \\
\hline Melibiose & - \\
\hline D-Raffinose & - \\
\hline Rhamnose & - \\
\hline Ribose & - \\
\hline Salicin & - \\
\hline L-Sorbose & - \\
\hline
\end{tabular}

Table 1 (cont.)

\begin{tabular}{|c|c|}
\hline Compound & Utilization \\
\hline Starch & - \\
\hline Sucrose & - \\
\hline D-Tagatose & - \\
\hline Trehalose & - \\
\hline D-Turanose & - \\
\hline D-Xylose & - \\
\hline L-Xylose & - \\
\hline Methyl $\beta$-xyloside & - \\
\hline \multicolumn{2}{|l|}{ Organic acids } \\
\hline Acetate & + \\
\hline Crotonate & $+*$ \\
\hline Fumarate & + \\
\hline DL-Lactate & + \\
\hline Pyruvate & + \\
\hline Succinate & $+(\mathrm{v})$ \\
\hline Adipate & - \\
\hline Butyrate & - \\
\hline Caprate & - \\
\hline Citrate & - \\
\hline Gluconate & - \\
\hline 2-Ketogluconate & - \\
\hline 5-Ketogluconate & - \\
\hline Malate & - \\
\hline Propionate & - \\
\hline \multicolumn{2}{|l|}{ Alcohols } \\
\hline Adonitol & - \\
\hline D-Arabitol & - \\
\hline L-Arabitol & - \\
\hline Dulcitol & - \\
\hline Erythritol & - \\
\hline Ethanol & - \\
\hline Ethylene glycol & - \\
\hline Inositol & - \\
\hline Glycerol & - \\
\hline D-Mannitol & - \\
\hline Propan-1-ol & - \\
\hline Sorbitol & - \\
\hline Xylitol & - \\
\hline \multicolumn{2}{|l|}{ Aromatic compounds } \\
\hline Benzoate & $-(\mathrm{v})$ \\
\hline 4-Carboxybenzaldehyde & - \\
\hline$o$-Phthalate & - \\
\hline Phenylacetate & - \\
\hline$p$-Methylbenzoate & - \\
\hline Terephthalate & - \\
\hline Trimellitate & - \\
\hline
\end{tabular}

(CIP $104854^{\mathrm{T}}$ ) and S. maltophilia $\left(60.77^{\mathrm{T}}\right)$ found during this study was $65.9 \%$, significantly different from the value of $35 \%$ reported by Drancourt et al. (1997), which led them to propose S. africana as a novel species. This difference is probably due to the fact that the S1 nuclease (TCA) hybridization technique employed by these authors is known to produce 
Table 2. Action of antibiotics towards strain $A M X 19^{\top}$

Sensitivity: + , sensitive; - , not sensitive; \pm , intermediate sensitivity. For the amoxicillin + clavulanic acid test, the disk charge with the two compounds was 20 and $10 \mu \mathrm{g}$. For the piperacillin + tazobactam test, it was 75 and $10 \mu \mathrm{g}$. $\mathrm{MIC}_{\mathrm{eq}}$, Equivalent minimum inhibitory concentration according to the Comité de l'antibiogramme de la Société Française de Microbiologie (1997). The reported $\mathrm{MIC}_{\mathrm{eq}}$ for piperacillin and piperacillin + tazobactam correspond to those recommended for Pseudomonas aeruginosa.

\begin{tabular}{|c|c|c|}
\hline Antibiotic & Sensitivity & $\begin{array}{c}\mathrm{MIC}_{\mathrm{eq}} \\
\left(\mathrm{mg} \mathrm{l}^{-1}\right)\end{array}$ \\
\hline \multicolumn{3}{|c|}{ Aminoglycosides (inhibition of protein synthesis) } \\
\hline Amikacin $(30 \mu \mathrm{g})$ & + & $\leqslant 8$ \\
\hline Gentamicin (10 UI) & + & $\leqslant 4$ \\
\hline Netilmicin $(30 \mu \mathrm{g})$ & + & $\leqslant 4$ \\
\hline Tobramycin $(10 \mu \mathrm{g})$ & + & $\leqslant 4$ \\
\hline \multicolumn{3}{|c|}{ Fluoroquinolones (inhibition of nucleic acid synthesis) } \\
\hline Ciprofloxacin $(5 \mu \mathrm{g})$ & + & $\leqslant 1$ \\
\hline Ofloxacin $(5 \mu \mathrm{g})$ & + & $\leqslant 1$ \\
\hline \multicolumn{3}{|c|}{ Polypeptides (disruption of cell membranes) } \\
\hline Colistin (300 UI) & + & $\leqslant 2$ \\
\hline \multicolumn{3}{|c|}{$\begin{array}{l}\text { Sulfonamides + diaminopyrimidines (inhibition of folate } \\
\text { synthesis) }\end{array}$} \\
\hline $\begin{array}{l}\text { Trimethoprim }+ \text { sulfamethoxazole } \\
(1.25+23 \cdot 75 \mu \mathrm{g})\end{array}$ & + & $\leqslant 2 / 38$ \\
\hline \multicolumn{3}{|c|}{ Carbapenems (inhibition of peptidoglycan synthesis) } \\
\hline Imipenem $(10 \mu \mathrm{g})$ & - & $>8$ \\
\hline \multicolumn{3}{|c|}{ Cephems (inhibition of peptidoglycan synthesis) } \\
\hline Cefalotin $(30 \mu \mathrm{g})$ & - & $>32$ \\
\hline Cefotaxime $(30 \mu \mathrm{g})$ & - & $>32$ \\
\hline Ceftazidime $(30 \mu \mathrm{g})$ & + & $\leqslant 4$ \\
\hline \multicolumn{3}{|c|}{ Penicillins (inhibition of peptidoglycan synthesis) } \\
\hline Amoxicillin $(25 \mu \mathrm{g})$ & - & $>16$ \\
\hline Amoxicillin + clavulanic acid & - & $>16$ \\
\hline Piperacillin $(75 \mu \mathrm{g})$ & + & $\leqslant 16$ \\
\hline Piperacillin + tazobactam & + & $\leqslant 16$ \\
\hline Ticarcillin $(75 \mu \mathrm{g})$ & \pm & $\geqslant 16-64$ \\
\hline
\end{tabular}

rather low binding values compared with the spectrophotometric method (Hauben et al., 1999).

\section{DISCUSSION}

\section{Identification}

Strains AMX 17 and AMX 19 ${ }^{\mathrm{T}}$ exhibited very high similarity in their CFA profiles and identical partial $16 \mathrm{~S}$ rRNA sequences (500 bp); we therefore assumed that they belong to the same species, and strain AMX $19^{\mathrm{T}}$ was chosen arbitrarily as the type strain. The phylogenetic analysis disclosed without doubt that strain AMX $19^{\mathrm{T}}$ is affiliated to the family Xanthomonadaceae of the $\gamma$-subclass of the Proteobacteria and, within this family, to the genera Stenotrophomonas and Xanthomonas. This is in agreement with its $\mathrm{CFA}$ profile and $\mathrm{G}+\mathrm{C}$ content and the fact that it is a strictly aerobic, Gram-negative, non-sporulating, motile, straight to curved, rod-shaped bacteria (Palleroni \& Bradbury, 1993; Vauterin et al., 1995). Other phenotypic traits, such as testing positive for oxidase, the presence of a nitrate reductase and an optimum growth temperature over $30^{\circ} \mathrm{C}$ indicate that strain AMX $19^{\mathrm{T}}$ cannot be a member of Xanthomonas and that it is more likely to be a member of Stenotrophomonas, despite its monotrichous flagellation. In accordance with these phenotypic characters, analysis of the 16S rRNA sequence of strain AMX $19^{\mathrm{T}}$ revealed that the known Stenotrophomonas species were its closest relatives together with $P$. pictorum ATCC $23328^{\mathrm{T}}$ (Fig. 2). As strain AMX $19^{\mathrm{T}}$ shares only $96 \cdot 7$ and $96.4 \%$ sequence similarity with $S$. maltophilia LMG $958^{\mathrm{T}}$ and $S$. africana CIP $104854^{\mathrm{T}}$, it cannot be a member of either of these species (Stackebrandt \& Goebel, 1994). The DNA-DNA hybridization values of strain AMX $19^{\mathrm{T}}$ with S. maltophilia CIP $60.77^{\mathrm{T}}$ $(31 \%)$ and S. africana CIP $104854^{\mathrm{T}}(26.7 \%)$, which were significantly below the $70 \%$ proposed by Wayne et al. (1987), corroborate this result. It is interesting to note that, in contrast to $S$. africana CIP $104854^{\mathrm{T}}$ and $S$. maltophilia LMG $958^{\mathrm{T}}$ or LMG 11114, strain AMX $19^{\mathrm{T}}$ was never identified as $S$. maltophilia by the MIDI fatty acid identification system or upon use of classical biochemical identification kits such as API $20 \mathrm{NE}$ strips (Drancourt et al., 1997; Hauben et al., 1999; this study). This attests to the fact that AMX $19^{\mathrm{T}}$ is phenotypically distinct from these species and that it can be distinguished from them easily by simple, commonly available identification tools. The $16 \mathrm{~S}$ rRNA phylogenetic analysis did not, however, allow us to discriminate strain AMX $19^{\mathrm{T}}$ at the species level from $P$. pictorum ATCC $23328^{\mathrm{T}}(98.01 \%$ similarity) or S. nitritireducens DSM $12575^{\mathrm{T}}$ (98.6\% similarity). The DNA-DNA reassociation experiments performed to resolve the phylogenetic relationship of these bacteria demonstrated without ambiguity that AMX $19^{\mathrm{T}}$ cannot be affiliated to $P$. pictorum (hybridization of only $43.6 \%$ ). This is consistent with the fact that, in the dendrogram constructed from the CFA patterns, $P$. pictorum linked with strain AMX $19^{\mathrm{T}}$ at a Euclidian distance of more than 15 , which is much higher than the usual cut-off limit between species (Fig. 1). The genomic information obtained during this study, combined with comparative phenotypic analysis done by others (Van den Mooter \& Swings, 1990; Oyaizu \& Komagata, 1983), suggests that $P$. pictorum should be affiliated to the genus Stenotrophomonas. A DNADNA hybridization value below $70 \%$ was also observed between $S$. nitritireducens DSM $12575^{\mathrm{T}}$ and AMX $19^{\mathrm{T}}$. Since this value $(65.8 \%)$ is close to $70 \%$, one could argue that this is not sufficient to separate the two strains in different species, particularly when one considers that the type species of Stenotrophomonas (S. maltophilia), while phenotypically very homogeneous, appears to be characterized by significant genomic diversity (16S rRNA similarity from 91.6 to $99 \cdot 7 \%$, DNA-DNA hybridization from 5 to $95 \%$; Hauben et al., 1999). Nevertheless, in the case of AMX 
Table 3. Fatty acid profiles of strains $A M X 19^{\top}$ and $A M X 17$ compared with those of Stenotrophomonas species

Values are percentages of total fatty acids.

\begin{tabular}{|c|c|c|c|c|c|}
\hline Fatty acid & $\operatorname{AMX} 19^{\mathrm{T}}$ & AMX 17 & $\begin{array}{l}\text { S. nitritireducens } \\
\text { DSM } 12575^{\mathrm{T}}\end{array}$ & $\begin{array}{l}\text { S. maltophilia } \\
\text { CIP } 60.77^{\mathrm{T}}\end{array}$ & $\begin{array}{c}\text { S. africana } \\
\text { CIP } 104854^{\mathrm{T}}\end{array}$ \\
\hline $9: 0$ & $0 \cdot 03$ & & & & \\
\hline $10: 0$ iso & 0.97 & $1 \cdot 38$ & & & \\
\hline $10: 0$ & $0 \cdot 24$ & $0 \cdot 26$ & & $0 \cdot 70$ & $0 \cdot 60$ \\
\hline $11: 0$ iso & $4 \cdot 06$ & $4 \cdot 29$ & $5 \cdot 05$ & $3 \cdot 43$ & $3 \cdot 11$ \\
\hline $11: 0$ anteiso & $0 \cdot 30$ & $0 \cdot 34$ & $0 \cdot 39$ & & \\
\hline $10: 03 \mathrm{OH}$ & $0 \cdot 04$ & & & $0 \cdot 22$ & $0 \cdot 21$ \\
\hline $12: 0$ iso & $0 \cdot 14$ & $0 \cdot 24$ & & & \\
\hline $11: 0$ iso $3 \mathrm{OH}$ & $1 \cdot 84$ & $2 \cdot 03$ & $2 \cdot 43$ & $1 \cdot 74$ & $1 \cdot 58$ \\
\hline $11: 03 \mathrm{OH}$ & $0 \cdot 10$ & $0 \cdot 12$ & $0 \cdot 33$ & & \\
\hline $13: 0$ iso & 0.60 & $0 \cdot 71$ & $0 \cdot 86$ & 0.73 & 0.66 \\
\hline $13: 0$ anteiso & $0 \cdot 06$ & $0 \cdot 11$ & & & \\
\hline $12: 0$ iso $3 \mathrm{OH}$ & $1 \cdot 85$ & $2 \cdot 22$ & $1 \cdot 45$ & & \\
\hline $12: 03 \mathrm{OH}$ & $0 \cdot 60$ & $0 \cdot 74$ & $1 \cdot 24$ & $3 \cdot 01$ & $3 \cdot 01$ \\
\hline $14: 0$ iso & $6 \cdot 59$ & $8 \cdot 68$ & $3 \cdot 52$ & $0 \cdot 54$ & $0 \cdot 86$ \\
\hline $14: 1 \omega 5 c$ & $0 \cdot 16$ & $0 \cdot 2$ & & & \\
\hline $14: 0$ & 0.92 & 0.97 & $1 \cdot 37$ & $4 \cdot 44$ & $4 \cdot 32$ \\
\hline $13: 0$ iso $3 \mathrm{OH}$ & $1 \cdot 26$ & $1 \cdot 62$ & $2 \cdot 18$ & $3 \cdot 54$ & $3 \cdot 22$ \\
\hline $13: 02 \mathrm{OH}$ & $0 \cdot 23$ & $0 \cdot 29$ & $0 \cdot 57$ & $0 \cdot 25$ & $0 \cdot 29$ \\
\hline $15: 1$ iso $F$ & $2 \cdot 75$ & $2 \cdot 89$ & $2 \cdot 67$ & $1 \cdot 30$ & $1 \cdot 16$ \\
\hline $15: 0$ iso & $35 \cdot 95$ & 33.64 & 35 & $36 \cdot 65$ & $36 \cdot 68$ \\
\hline $15: 0$ anteiso & $5 \cdot 19$ & $5 \cdot 02$ & $8 \cdot 23$ & 6.96 & $8 \cdot 78$ \\
\hline $15: 1 \omega 8 c$ & $0 \cdot 10$ & & & & \\
\hline $15: 1 \omega 6 c$ & $0 \cdot 39$ & $0 \cdot 29$ & & & \\
\hline $15: 0$ & $0 \cdot 63$ & $0 \cdot 47$ & $1 \cdot 83$ & $0 \cdot 33$ & $0 \cdot 55$ \\
\hline $16: 1$ iso $\mathrm{H}$ & $0 \cdot 13$ & $0 \cdot 19$ & & & \\
\hline $16: 0$ iso & $10 \cdot 20$ & $10 \cdot 50$ & $5 \cdot 38$ & $0 \cdot 62$ & $1 \cdot 15$ \\
\hline $16: 1 \omega 9 c$ & $0 \cdot 87$ & $0 \cdot 79$ & 0.97 & $3 \cdot 72$ & $3 \cdot 33$ \\
\hline $16: 0$ & $2 \cdot 28$ & $2 \cdot 14$ & $4 \cdot 80$ & $6 \cdot 51$ & $6 \cdot 48$ \\
\hline $15: 0$ iso $3 \mathrm{OH}$ & $0 \cdot 10$ & & & & \\
\hline Iso $17: 1 \omega 9 c$ & $12 \cdot 72$ & $12 \cdot 18$ & $12 \cdot 87$ & $4 \cdot 51$ & $4 \cdot 38$ \\
\hline $17: 0$ iso & $2 \cdot 02$ & $1 \cdot 55$ & $3 \cdot 33$ & $3 \cdot 10$ & $2 \cdot 96$ \\
\hline $17: 0$ anteiso & & & & $0 \cdot 17$ & $0 \cdot 24$ \\
\hline $17: 1 \omega 8 c$ & $0 \cdot 47$ & $0 \cdot 38$ & $1 \cdot 02$ & & $0 \cdot 18$ \\
\hline 17:0 cyclo & & & $1 \cdot 23$ & & \\
\hline $17: 0$ & $0 \cdot 11$ & & & & \\
\hline $18: 1 \omega 9 c$ & $0 \cdot 11$ & $0 \cdot 17$ & & $1 \cdot 43$ & $1 \cdot 31$ \\
\hline $18: 1 \omega 7 c$ & $0 \cdot 10$ & $0 \cdot 17$ & & 0.77 & 0.78 \\
\hline $18: 0$ & & $0 \cdot 21$ & $0 \cdot 23$ & & \\
\hline $19: 0$ iso & & & & $0 \cdot 40$ & $0 \cdot 32$ \\
\hline
\end{tabular}

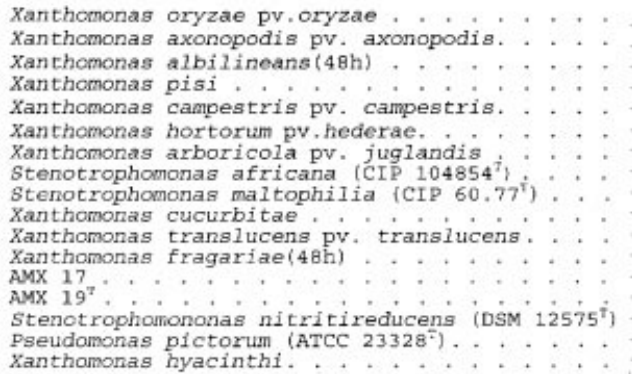

Xanthomonas hyacinthi.

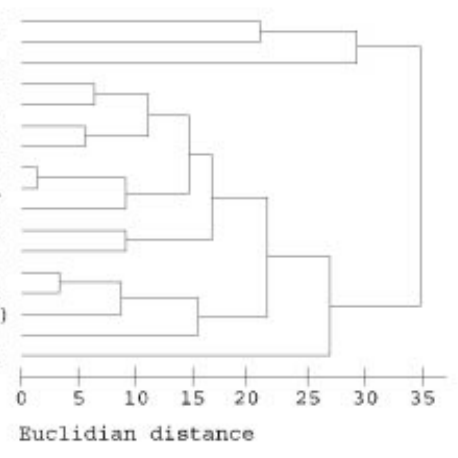

Fig. 1. Dendrogram generated from CFA compositions showing the relationship of strains AMX 17 and AMX $19^{\top}$ with 11 Xanthomonas species and all Stenotrophomonas species. 


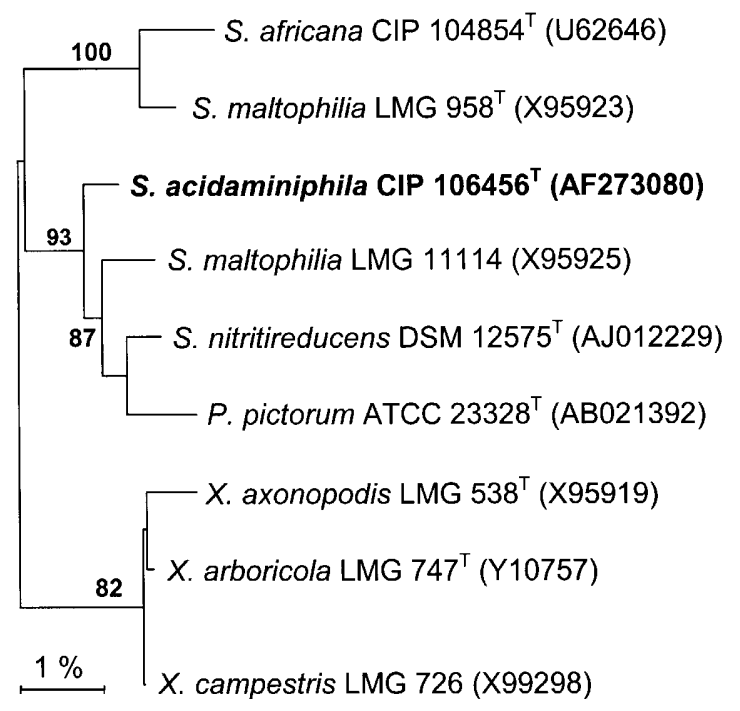

Fig. 2. Phylogenetic dendrogram showing the position of strain AMX $19^{\top}\left(=\right.$ CIP $\left.106456^{\top}\right)$ among representative members of the genus Stenotrophomonas and other closely related Proteobacteria. Bar, 1 nucleotide substitution per 100 nucleotides. Percentages at nodes correspond to bootstrap values based on 1000 resamplings. Only values greater than $80 \%$ were considered significant and therefore are reported.

$19^{\mathrm{T}}$, the genomic difference from $S$. nitritireducens DSM $12575^{\mathrm{T}}$ is clearly correlated by at least 17 phenotypic differences, including different spectra of substrates used (Table 4), a different CFA pattern (Table 3), the presence of a nitrate reductase, the absence of $\mathrm{N}_{2} \mathrm{O}$ formation upon $\mathrm{NO}_{3}$ reduction and the ability to hydrolyse aesculin.

On the basis of the above-mentioned results, we propose that strains AMX $19^{\mathrm{T}}\left(=\mathrm{DSM} 13117^{\mathrm{T}}=\right.$ ATCC $700916^{\mathrm{T}}=$ CIP $106456^{\mathrm{T}}$ ) and AMX 17 represent a novel species of genus Stenotrophomonas, Stenotrophomonas acidaminiphila sp. nov.

\section{Ecological aspects}

The isolation of strain AMX $19^{\mathrm{T}}$, a strict aerobe, from the sludge of an anaerobic reactor raises the question of whether such a system corresponds to its usual biotope or whether it was found there by accident. At the time of isolation, the anaerobic reactor was fed with non-sterilized wastewater and, as a consequence, strain AMX $19^{\mathrm{T}}$ could have been introduced to the system in this way. Nevertheless, 3.5 months after switching feeding to sterilized wastewater, strains with CFA profiles identical to AMX $19^{\mathrm{T}}$ were still found in the reactor at levels as high as $3 \times 10^{5}$ c.f.u. $\mathrm{ml}^{-1}$. Since strain AMX $19^{\mathrm{T}}$ is unable to sporulate or to produce any form of resistance, its presence in such a biotope for such a long period of time suggests that it was metabolically active even as ultramicrobacteria (Iizuka et al., 1998) and that it is a permanent member of its microflora. Since the wastewater contained a low concentration of nitrate $\left(3 \cdot 1 \mathrm{mg}^{-1}, 50 \mu \mathrm{M}\right)$, survival
Table 4. Characteristics, other than fatty acids, that differentiate strain AMX $19^{\top}$ from its closest relative, S. nitritireducens

Data for S. nitritireducens were taken from Finkmann et al. (2000), Lipsky \& Altendorf (1997) and this study (sensitivity to antibiotics). Characteristics are scored as: + or - , test is positive (negative), a substrate is used (not used) or the strain is sensitive (not sensitive) to the corresponding antibiotic; $(+)$, variable; \pm , sensitivity of the strain to the antibiotic is intermediate.

\begin{tabular}{|lcc|}
\hline Characteristic & AMX 19 & $\begin{array}{c}\text { S. nitritireducens } \\
\text { DSM 12575 }\end{array}$ \\
\hline Oxidase & + & - \\
Aesculin hydrolysis & + & - \\
Nitrate reductase & + & - \\
Production of $\mathrm{N}_{2} \mathrm{O}$ from & - & + \\
nitrite reduction & & \\
Substrate utilization: & & - \\
L-Proline & + & - \\
Maltose & + & - \\
D-Mannose & + & + \\
Fumarate & + & - \\
Propionate & - & + \\
Pyruvate & + & + \\
Succinate & $(+)$ & + \\
Sensitivity to antibiotics: & & - \\
Cefotaxime $(30 \mu \mathrm{g})$ & - & \\
Imipenem $(10 \mu \mathrm{g})$ & - & \\
Ticarcillin $(75 \mu \mathrm{g})$ & \pm & \\
Trimethoprim + & + & \\
sulfamethoxazole & & \\
(1.25+23.75 $\mu \mathrm{g})$ & & \\
& & \\
\hline
\end{tabular}

by denitrification was a possibility. This notwithstanding, cultures of strains AMX $19^{\mathrm{T}}$ with diluted $(1: 3)$

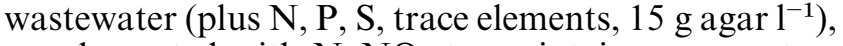
supplemented with $\mathrm{NaNO}_{3}$ to maintain a concentration of $3.1 \mathrm{mg}$ nitrate $\mathrm{l}^{-1}$, always failed to produce colonies in anaerobic jars even after 1 month of incubation at $35^{\circ} \mathrm{C}$. As a consequence, the only logical explanation for the permanence of this strain seems related to the fact that the wastewater was not de-aerated before feeding. Under these conditions, the reactor, even if macroscopically anaerobic $\left(E_{\mathrm{h}}=-101 \pm 20 \cdot 4 \mathrm{mV}\right.$; $\mathrm{CH}_{4}$ production; no oxygen detected at the reactor outlet), was in reality slightly aerated. Based on the concentration of $\mathrm{O}_{2}$ in the wastewater $\left(1.6 \mathrm{mg} \mathrm{l}^{-1}\right)$, it can be estimated that the system received $0.8 \mathrm{mg} \mathrm{O}_{2}$ $1_{\text {reactor }}^{-1}$ day $^{-1}$, which represents less than $0.035 \%$ of the organic loading rate, confirming that the greater part of the organic matter was necessarily degraded anaerobically. Strain AMX $19^{\mathrm{T}}$ could have survived in the system at the expense of acetate or benzoate, which are the two wastewater organic pollutants that it uses as carbon sources, and oxygen, for which it has a high affinity (i.e. $K_{\mathrm{m}}$ for $\mathrm{O}_{2}$ as low as $8 \mu \mathrm{g} \mathrm{O}_{2} 1^{-1}$ or $0.25 \mu \mathrm{M}$ with acetate as carbon source). The significance of the 
loss by freshly isolated strains of AMX $19^{\mathrm{T}}$ of the ability to use benzoate upon subculturing on solid media is not known, but similar results were observed previously for benzoate and hydrocarbons with $S$. maltophilia strains isolated from the soils of rice fields and oil fields (Garcia et al., 1981; Palleroni \& Bradbury, 1993). The carbonaceous substrates available to strain AMX $19^{\mathrm{T}}$ were, however, probably not restricted to those present in the wastewater. For instance, various organic compounds may be released during cell lysis and others, such as exopolymers, excreted by several organisms. These compounds include amino acids and peptides, which have been found as preferred substrates of strain AMX 19 ${ }^{\mathrm{T}}$. Moreover, in contrast to what happens with acetate, AMX $19^{\mathrm{T}}$ would not have to compete for them with methanogenic bacteria. Since strain AMX $19^{\mathrm{T}}$ was isolated from the environment, its impact on human health is not known, and it would be interesting to evaluate it, considering that some of its close relatives ( $S$. maltophilia and $S$. africana) are recognized opportunistic pathogens. The preliminary information given by the antibiogram suggests, nevertheless, that it is sensitive to a large panel of antimicrobial agents presently available for therapeutics.

\section{Description of Stenotrophomonas acidaminiphila sp. nov.}

Stenotrophomonas acidaminiphila (a.ci.da.mi.ni.phi'la. N.L. acidum acid; N.L. n. aminum amine; N.L. fem. adj. phila from Gr. adj. philos loving; N.L. adj. acidaminiphila loving amino acids).

Cells are straight to curved rods, $0.5 \mu \mathrm{m}$ wide and $1.5-2.5 \mu \mathrm{m}$ long. Gram-negative, non-sporulating, strictly aerobic bacterium. Motile by one polar flagellum. Pale yellow colonies on common nutritive medium. Tests for catalase, oxidase, aesculin hydrolysis, Tween 80 esterase and nitrite and nitrate reductases are positive. Substrates utilized are listed in Table 1. Benzoate utilization lost upon subculturing. Casamino acids $\left(0 \cdot 1 \mathrm{~g} \mathrm{l}^{-1}\right)$ are required for growth. Antibiotic susceptibility: amikacin, ceftazidime, ciprofloxacin, colistin, gentamicin, netilmicin, ofloxacin, piperacillin, ticarcillin, trimethropim sulfamethoxazole and tobramycin. Predominant fatty acids are, in order of abundance: 15:0 iso, $17: 1$ iso $\omega 9 c, 16: 0$ iso, 14:0 iso, 15:0 anteiso and 11:0 iso. Trace fatty acids that distinguish the species from other Stenotrophomonas species are 10:0 iso; $12: 0$ iso; $13: 0$ anteiso, $14: 1 \omega 5 c$, $15: 1 \omega 6 c$ and $16: 1$ iso $\mathrm{H}$. The $\mathrm{pH}$ range for growth is $5 \cdot 0-9 \cdot 0$, with optimum growth at $\mathrm{pH}$ 6.0-7.0. Temperature range for growth, $<20-42^{\circ} \mathrm{C}$, optimum at $30-35^{\circ} \mathrm{C}$. The DNA $\mathrm{G}+\mathrm{C}$ content is $66 \cdot 9 \pm$ $0.5 \mathrm{~mol} \%$.

Habitat: isolated from anaerobic sludge of a lab-scale UASB reactor, treating the petrochemical wastewater of a purified terephthalic acid plant in Mexico. The type strain is AMX $19^{\mathrm{T}}\left(=\mathrm{DSM} 13117^{\mathrm{T}}=\mathrm{ATCC}\right.$ $700916^{\mathrm{T}}=$ CIP $\left.106456^{\mathrm{T}}\right)$.

\section{ACKNOWLEDGEMENTS}

For the realization of this work, A.S.O. received a postdoctoral fellowship from IRD and E. A. received a scholarship from the Government of Togo. S.T. was supported financially successively by IRD and the Secretaria de Relaciones Exteriores (Foreign Affairs) of Mexico. Thanks are due to Martine Keridjian of the Pasteur Institute for the respective determination of some of the biochemical characteristics and to Nicolas Fortineau of Pasteur Cerba for determining the antibiotic susceptibility of strain AMX $19^{\mathrm{T}}$. Thanks are due also to Pierre Thomas for electron microscope facilities, Frédéric Verhe and Jaime Perez Trevilla for technical assistance and Sylvie Escoffier, Marie Laure Fardeau, Jean-Louis Garcia and Pierre Roger for fruitful discussions and support. Special thanks go to Karen Dohrman of Microbial ID Inc., John Bartell of MIDI Labs and Peter Schumann of DSMZ who, besides the respective determination of CFA, 16S rRNA sequences and DNA hybridization, were always ready to give us professional and fine suggestions on the corresponding techniques. Finally, we cannot forget Fernando Varela and Roberto Marcelo, from Tereftalatos Mexicanos SA, who gave us the wastewater and inoculum for the operation of the lab-scale reactor from which strains AMX 17 and $19^{\mathrm{T}}$ were isolated.

\section{REFERENCES}

Aznar, R., Alcaide, E. \& Garay, E. (1992). Numerical taxonomy of pseudomonads isolated from water, sediments and eels. Syst Appl Microbiol 14, 235-246.

Bauer, A. W., Kirby, W. M. M., Sherris, J. C. \& Turk, M. (1966). Antibiotic susceptibility testing by a standardized single disk method. Am J Clin Pathol 45, 493-496.

Boonchan, S., Britz, M. L. \& Stanley, G. A. (1998). Surfactantenhanced biodegradation of high molecular weight polycyclic aromatic hydrocarbons by Stenotrophomonas maltophilia. Biotechnol Bioeng 59, 482-494.

Borowicz, J. J., Brishammer, S. \& Gerhardson, B. (1995). A Xanthomonas maltophilia isolate tolerating up to 1 percentage sodium azide in Tris/HCl buffer. World J Microbiol Biotechnol 11, 236-237.

Britz, T. J., Spangenberg, G. \& Venter, C. A. (1994). Acidogenic microbial species diversity in anaerobic digesters treating different substrates. Water Sci Technol 30 (12), 55-61.

Cashion, P., Holder-Franklin, M. A., McCully, J. \& Franklin, M. (1977). A rapid method for the base ratio determination of bacterial DNA. Anal Biochem 81, 461-466.

Comité de l'antibiogramme de la Société Française de Microbiologie (1997). Communiqué 1997. Pathol Biol 45, 1-12.

Daniels, L., Hanson, R. S. \& Phillips, J. A. (1994). Chemical analysis. In Methods for General and Molecular Bacteriology, chapter 22, pp. 512-554. Edited by P. Gerhardt, R. G. E. Murray, W. A. Wood \& N. R. Krieg. Washington, DC: American Society for Microbiology.

De Ley, J., Cattoir, H. \& Reynaerts, A. (1970). The quantitative measurement of DNA hybridization from renaturation rates. Eur $J$ Biochem 12, 133-142.

Denton, M. \& Kerr, K. G. (1998). Microbiological and clinical aspects of infections associated with Stenotrophomonas maltophilia. Clin Microbiol Rev 11, 57-80.

Drancourt, M., Bollet, C. \& Raoult, D. (1997). Stenotrophomonas africana sp. nov., an opportunistic human pathogen in Africa. Int J Syst Bacteriol 47, 160-163.

El-Mamouni, R., Guiot, S. R., Leduc, R. \& Costerton, J. W. (1995). Characterization of different microbial nuclei as potential precursors of anaerobic granulation. J Biotechnol 39, 239-249. 
Escara, J. F. \& Hutton, J. R. (1980). Thermal stability and renaturation of DNA in dimethyl sulfoxide solutions: acceleration of the renaturation rate. Biopolymers 19, 1315-1327.

Fajardo, C., Guyot, J. P., Macarie, H. \& Monroy, O. (1997). Inhibition of anaerobic digestion by terephthalic acid and its anaerobic byproducts. Water Sci Technol 36 (6-7), 83-90.

Felsenstein, J. (1993). PHYLIP (Phylogenetic Inference Package) version 3.51c. Distributed by the author. Department of Genetics, University of Washington, Seattle, WA, USA.

Finkmann, W., Altendorf, K., Stackebrandt, E. \& Lipski, A. (2000). Characterization of $\mathrm{N}_{2} \mathrm{O}$-producing Xanthomonas-like isolates from biofilters as Stenotrophomonas nitritireducens sp. nov., Luteimonas mephitis gen. nov., sp. nov. and Pseudoxanthomonas broegbernensis gen. nov., sp. nov. Int J Syst Evol Microbiol 50, 273-282.

Garcia, J.-L., Roussos, S. \& Bensoussan, M. (1981). Taxonomical study of denitrifying bacteria isolated on benzoate in Senegalese rice fields. Cah ORSTOM Ser Biol 43, 13-25 (in French).

Gomez, J., Mendez, R. \& Lema, J. M. (1996). The effect of antibiotics on nitrification processes. Batch assays. Appl Biochem Biotechnol 57/58, 869-876.

Guyot, J.-P., Ramirez, F. \& Ollivier, B. (1994). Synergistic degradation of acetamide by methanogens and an aerobic Gram-positive rod. Appl Microbiol Biotechnol 42, 452-456.

Hakulinen, R., Woods, S., Ferguson, J. \& Benjamin, M. (1985). The role of facultative anaerobic micro-organisms in anaerobic biodegradation of chlorophenols. Water Sci Technol 17, 289-301.

Hauben, L., Vauterin, L., Moore, E. R. B., Hoste, B. \& Swings, J. (1999). Genomic diversity of the genus Stenotrophomonas. Int J Syst Bacteriol 49, 1749-1760.

Hugh, R. \& Ryschenkow, E. (1961). Pseudomonas maltophilia, an Alcaligenes-like species. J Gen Microbiol 26, 123-132.

Huß, V. A. R., Festel, H. \& Schleifer, K. H. (1983). Studies on the spectrometric determination of DNA hybridization from renaturation rates. Syst Appl Microbiol 4, 184-192.

lizuka, T., Yamanaka, S., Nishiyama, T. \& Hiraishi, A. (1998). Isolation and phylogenetic analysis of aerobic copiotrophic ultramicrobacteria from urban soil. J Gen Appl Microbiol 44, 75-84.

Jahnke, K.-D. (1992). Basic computer program for evaluation of spectroscopic DNA renaturation data from GILFORD system 2600 spectrometer on a PC/XT/AT type personal computer. J Microbiol Methods 15, 61-73.

Jahnke, K.-D. \& Bahnweg, G. (1986). Assessing natural relationships in the basidiomycetes by DNA analysis. Trans Br Mycol Soc 87, 175-191.

Juhnke, M. E., Mathre, D. E. \& Sands, D. C. (1987). Identification and characterization of rhizospere-competent bacteria of wheat. Appl Environ Microbiol 53, 2793-2799.

Jukes, T. H. \& Cantor, C. R. (1969). Evolution of protein molecules. In Mammalian Protein Metabolism, vol. 3, pp. 21-132. Edited by H. N. Munro. New York: Academic Press.

Lambert, B., Meire, P., Joos, H., Lens, P. \& Swings, J. (1990). Fastgrowing, aerobic, heterotrophic bacteria from rhizosphere of young sugar beet plants. Appl Environ Microbiol 56, 3375-3381.

Lane, D. J. (1991). 16S/23S rRNA sequencing. In Nucleic Acid Techniques in Bacterial Systematics, pp. 115-175. Edited by E. Stackebrandt \& M. Goodfellow. Chichester: Wiley.

Leifert, C. \& Waites, W. M. (1992). Bacterial growth in plant tissue culture media. J Appl Bacteriol 72, 460-466.

Lipsky, A. \& Altendorf, K. (1997). Identification of heterotrophic bacteria isolated from ammonia-supplied experimental biofilters. Syst Appl Microbiol 20, 448-457.

Maidak, B. L., Olsen, G. J., Larsen, N., Overbeek, R., McCaughey, M. J. \& Woese, C. R. (1996). The Ribosomal Database Project (RDP). Nucleic Acids Res 24, 82-85.

Mesbah, M., Premachandran, U. \& Whitman, W. B. (1989). Precise measurement of the $\mathrm{G}+\mathrm{C}$ content of deoxyribonucleic acid by highperformance liquid chromatography. Int J Syst Bacteriol 39, 159-167.
Miller, L. T. (1982). Single derivatization method for routine analysis of bacterial whole-cell fatty acid methyl esters, including hydroxy acids. $J$ Clin Microbiol 16, 584-586.

Moore, E. R. B., Krüger, A. S., Hauben, L., Seal, S. E., De Baere, R., De Wachter, R., Timmis, K. N. \& Swings, J. (1997). 16S rRNA gene sequence analysis and inter- and intrageneric relationships of Xanthomonas species and Stenotrophomonas maltophilia. FEMS Microbiol Lett 151, 145-153.

Ng, A., Melvin, W. T. \& Hobson, P. N. (1994). Identification of anaerobic digester bacteria using a polymerase chain reaction method. Bioresour Technol 47, 73-80.

Noeth, C., Britz, T. J. \& Joubert, W. A. (1988). The isolation and characterization of the aerobic endospore-forming bacteria present in the liquid phase of an anaerobic fixed-bed digester, while treating a petrochemical effluent. Microb Ecol 16, 233-240.

Oyaizu, H. \& Komagata, K. (1983). Grouping of Pseudomonas species on the basis of cellular fatty acid composition and the quinone system with special reference to the existence of 3-hydroxy fatty acids. J Gen Appl Microbiol 29, 17-40.

Palleroni, N. J. \& Bradbury, J. F. (1993). Stenotrophomonas, a new bacterial genus for Xanthomonas maltophilia (Hugh 1980) Swings et al. 1983. Int J Syst Bacteriol 43, 606-609.

Sasser, M. (1990). Identification of Bacteria by Gas Chromatography of Cellular Fatty Acids. Technical Note no. 101. Newark, DE: MIDI Inc. Smibert, R. M. \& Krieg, W. R. (1994). Phenotypic characterization. In Methods for General and Molecular Bacteriology, chapter 25, pp. 607-654. Edited by P. Gerhardt, R. G. E. Murray, W. A. Wood \& N. R. Krieg. Washington, DC: American Society for Microbiology.

Stackebrandt, E. \& Goebel, B. M. (1994). Taxonomic note: a place for DNA-DNA reassociation and 16S rRNA sequence analysis in the present species definition in bacteriology. Int $J$ Syst Bacteriol 44, 846-849.

Stanier, R. Y., Palleroni, N. J. \& Doudoroff, M. (1966). The aerobic pseudomonads: a taxonomic study. J Gen Microbiol 43, 159-271.

Swings, J., De Vos, P., Van den Mooter, M. \& De Ley, J. (1983). Transfer of Pseudomonas maltophilia Hugh 1981 to the genus Xanthomonas as Xanthomonas maltophilia (Hugh 1981) comb. nov. Int J Syst Bacteriol 33, 409-413.

Toerien, D. F. \& Hattingh, W. H. J. (1969). Anaerobic digestion. I. The microbiology of anaerobic digestion. Water Res 3, 385-416.

Van den Mooter, M. \& Swings, J. (1990). Numerical analysis of 295 phenotypic features of 266 Xanthomonas strains and related strains and an improved taxonomy of the genus. Int J Syst Bacteriol 40, 348-369.

Van Zyl, E. \& Steyn, P. L. (1992). Reinterpretation of the taxonomic position of Xanthomonas maltophilia and taxonomic criteria in this genus. Request for an Opinion. Int J Syst Bacteriol 42, 193-198.

Vauterin, L., Hoste, B., Kersters, K. \& Swings, J. (1995). Reclassification of Xanthomonas. Int J Syst Bacteriol 45, 472-489.

Wallace, W. H., Rice, J. F., White, D. C. \& Sayler, G. S. (1994). Distribution of alginate genes in bacterial isolates from corroded metal surfaces. Microb Ecol 27, 213-223.

Wang, R.-F., Pothuluri, J. V., Steele, R. S., Paine, D. D., Assaf, N. A. \& Cerniglia, C. E. (1998). Molecular identification of a Stenotrophomonas species used in the bioassay for erythromycin in aquaculture samples. Mol Cell Probes 12, 249-254.

Wayne, L. G., Brenner, D. J., Colwell, R. R. \& 9 other authors (1987). International Committee on Systematic Bacteriology. Report of the ad hoc committee on reconciliation of approaches to bacterial systematics. Int J Syst Bacteriol 37, 463-464.

Wilkinson, K. G., Dixon, K. W., Sivasithamparam, K. \& Ghisalberti, E. L. (1994). Effect of IAA on symbiotic germination of an Australian orchid and its production by orchid-associated bacteria. Plant Soil 159, 291-295.

Yang, P., Vauterin, L., Vancanneyt, M., Swings, J. \& Kersters, K. (1993). Application of fatty acid methyl esters for the taxonomic analysis of the genus Xanthomonas. Syst Appl Microbiol 16, 47-71. 